\title{
FUTURE IN THE PAST: THE PROBLEM OF VALUES IN TRANSATLANTIC RELATIONS
}

\begin{abstract}
Ana- Maria Stoian
Ana-Maria Stoian has just graduated History - International Relations and European Studies at the Babes-Bolyai University of Cluj-Napoca (Romania). From this autumn she will be MA student in International Studies, specialization in History and International Politics at the Graduate Institute of International Studies in Geneva (HEI), where she was awarded with a full scholarship.
\end{abstract}

\begin{abstract}
This paper discusses the importance of norms and values in the transatlantic relations. Beginning with the values that shaped the transatlantic partnership at the end of the Second World War, the analysis questions the redefinition of transatlantic values at the beginning of the $21^{\text {st }}$ century, emphasizing patterns of convergence and divergence. Using a comparative approach, the article presents values, norms and principles explaining the domestic and international behaviour of the US and the EU. The main argument of the paper is that there are not two different sets of values, a European and an American one, but a single transatlantic set of values (a Western one), with some distinct elements and approaches. There is not a great departure from the common matrix of values so that to endanger the US-European relationship indefinitely.
\end{abstract}

\section{Introduction}

The transatlantic relationship finds itself at the beginning of the $21^{\text {st }}$ century at a turning point in history that might result in the adoption of one of the following alternatives for the two sides: European bandwagoning towards the US, accommodation (assuming a relative equal partnership, but in which America maintains its preeminence), the attempt to balance the American hegemony together with other actors, or as a last option, the mutual avoidance. Certainly, in practice, none of these alternatives or options seems plausible, thus 
making a compromise solution depending on political will of the two parties and their relative power and interests the most probable way.

Analysing the evolution of the transatlantic relationship in the last years, we noticed the relative ambivalence and even ambiguity of these relations. They are characterized, on one hand, by an extremely high level of integration and interdependence (especially in the economic field, but also in the political-military and cultural fields), and on the other hand, by numerous tensions and confrontations undermining the validity of the transatlantic partnership $^{1}$ (Serfaty 2005: 1).

This paper approaches the normative dimension of the transatlantic relationship, intending to correlate the role of values, norms and principles with the more general framework of interaction between the US and the EU. We believe that in spite of numerous contradictions concerning issues of global interest, there is not a rift in the US-EU relationship that could paralyze these relations. The dynamics of the international system and the behaviour of the two actors have challenged the nature of the transatlantic relationship, generating its progressive redefinition, on the basis of a synthesis of traditional and new values. Therefore, we consider that we are far from hving two different systems of values, a European and an American one, but a single transatlantic set of values, with some distinct elements and approaches, specific to the US and EU internal and external policies and interests. So, the transatlantic disagreements do not arise from the incompatibility of values, but more from the means of applying these values and from the status dissonance between the two actors (Wohlforth 2004: 189). In our analyze we used a series of core documents that codified the transatlantic partnership and its shared values (The Atlantic Charter, The Charter of the United Nations, The North Atlantic Treaty, The New Transatlantic Agenda), as well as some distinct documents of the EU (The Constitutional Treaty, The Solana Strategy) and of the US (National Security Strategy) and relevant speeches of the US and EU leaders to illustrate our assumptions.

The problem of values as an analytical conceptualization of the international relations has won great importance in the last years. The study of the international relations has had to adjust to the new realities in a changing world, where the traditional rational choice paradigm could no longer explain the new evidence in the international relations.

\footnotetext{
${ }^{1}$ See the Kyoto Protocol Problem, The International Criminal Court, "the crisis" generated by the American intervention in Iraq, "the commercial wars".
} 
Shifting the unit of analysis from state to the individual represented as a member of collectivities, the epistemic approach underlines the role of beliefs and collective ideas, together with the cultural background in the agenda-setting of states. This post-positivist approach relates the role of beliefs and ideas to that of social identity, which represents, according to Manuel Castells "the process of construction of meaning on the basis of a cultural attribute(s) that are given priority over other sources of meaning" (Castells 1997: 6). This intersubjective construction of reality on the basis of norms, values and principles prove, in the context of the transatlantic relationship, that the current stage of the relationship cannot be evaluated objectively. The transatlantic relationship is constructed/reconstructed differently, depending on the leaders' perceptions and in accordance to domestic values.

\section{Traditional (basic) values}

The success of the transatlantic relationship is based on the matrix of common values that has animated both Europe and America, therefore creating an identity of values that finds its roots in the ideas of the Enlightenment: democracy, rule of law, human rights (Sampaio 2004: 3). These principles represent a constant in the transatlantic rhetoric and have stimulated any transatlantic joint action intended to defend and export them ${ }^{2}$.

One of the first documents referring to these principles and that contributed to the forging of a common transatlantic consciousness is The Atlantic Charter, signed on 14 August, 1941. The Atlantic Charter, although does not embody directly the principles of democracy, rule of law and human rights adheres to them through its vision of a postWorld War II peaceful and democratic world. The eight points of the Charter ${ }^{3}$ imposed a vision of the world in accordance to the values of the Atlantic allies.

\footnotetext{
${ }^{2}$ See The Second World War, The establishment of the UN, NATO, and The Helsinki System.

${ }^{3}$ In brief, the eight points were:

1. no territorial gains sought by the United States or the United Kingdom;

2. territorial adjustments must conform to the people involved;

3. the right to self-determination of peoples;

4. trade barriers lowered;

5. post-war disarmament;

6. freedom from want and fear;

7. freedom of the seas;

8. an association of nations.
} 
Another basic document comprising transatlantic values and seeking to universalize them is the Charter of the United Nations, signed on 26 June, 1945. The Preamble of the Charter reaffirms the need to promote peace, fundamental human rights, freedom, social and economic progress, international law. The establishment of the UN was an essential moment in the transatlantic partnership, representing, together with the creation of a plethora of organizations, regimes and agreements, the premises for global cooperation throughout a dense network of interaction.

The outbreak of the Cold War offered the impulse for strengthening and deepening the transatlantic relations. The transatlantic values become now Western values and constantly relate themselves in opposition with the communist ones (Garton Ash 2004: 4). So, the Cold War can be seen, not merely as a political-military confrontation between two superpowers, but also as an ideological confrontation between two antithetical systems of values. The Soviet threat determined the institutionalization of the transatlantic alliance through the establishment of NATO. The North Atlantic Treaty was designed to safeguard the freedom and security of its member countries and that of such principles as democracy, individual liberty and rule of law ${ }^{4}$, evolving into a defense community, and later into a security community. Also, the Treaty sanctions the principle of solidarity among all the allies, principle that prevailed over the military capability and contributions of the members (Gouré, 2004: 17). NATO assured the lasting connection of Euro-Atlantic area security, but marked in the same time the European security and defense dependence towards the American military and logistic capabilities.

Due to the high level of integration and interdependence, as well as shared values, the transatlantic security could then be considered a "pluralistic security community". According to Karl Deutsch (Deutsch apud Pfaltzgraff, Dougherty, 1990: 434) the pluralistic security community assumes three essential conditions: 1) compatibility of values among decision-makers, (2) mutual predictability of behaviour among decision-makers of the integrated units and (3) mutual responsiveness. The transatlantic security community

\footnotetext{
${ }^{4}$ „The Parties to this Treaty reaffirm their faith in the purposes and principles of the Charter of the United Nations and their desire to live in peace with all peoples and all governments.

They are determined to safeguard the freedom, common heritage and civilisation of their peoples, founded on the principles of democracy, individual liberty and the rule of law. They seek to promote stability and well-being in the North Atlantic area.

They are resolved to unite their efforts for collective defence and for the preservation of peace and security."
} 
represents a non anarchic space, opposed to the anarchy that dominates the international system (Kupchan 1998: 4). This imagined dichotomy Cosmos versus Chaos strengthened the Atlantic alliance and offered its main reason of existence. It aims to extend its stability and security projecting its own principles, norms and values, not only at regional level, but also at global level ${ }^{5}$.

Consequently, the transatlantic relationship consolidated at the end of the World War II as a community of values that ensured the promotion of freedom, democracy, human rights, rule of law, etc. This "historical partnership for democracy" (Dobrescu 2003: 161) materialized in successful and successive cooperation in almost every field of collaboration: the foundation of the Bretton-Woods System, Europe's reconstruction, the creation of GATT, NATO, the fall of communism, etc. Therefore, the transatlantic community sharing the same values transformed itself into a "community of action" (Serfaty 2004: 60) preoccupied by shaping the rest of the world. Although the Cold War was a period of great solidarity, the transatlantic relationship was not kept out of tensions and contradictions, most of them due to the US leading role, to some European acts of autonomy from the American predominance (especially French) or to some divergent visions. Still, on overall, the western alliance was characterized by regular consultations and unity. The leading role of the US was not felt as hegemonic, US actions were not seen as unilateralist because the allies participated in the decision making (Pond 2004: 25). The US was a primus inter pares and was very careful to maintain the relationship's cohesion.

The collapse of the Soviet Union and of the bipolar system marked the beginning of a new era in the international relations, in general, and for the transatlantic relationship, in particular. The evolution of the new world order, as well as the internal dynamics of the two actors (the US and the EU) has influenced their positioning in the international system and the relations within the transatlantic partnership.

The US was left without any major competitor. The removal of the traditional rival, the economic boom recorded after 1992, and the technological advance created favourable premises for the consolidation of the US power, America emerging now as the hegemon of the contemporary international relations. Appealing to its traditional messianism, its ideological superiority, its military power and dominant economy, influencing the main

\footnotetext{
${ }^{5}$ See The Enlargement Policy and The Neighborhood Policy of the EU, Clinton's Policy of Extending the Community of Democracies.
} 
international organizations (UN, WTO), the US wants to create a liberal world order, based on democracy and free trade. In this way, "the unipolar moment", seen as a consequence of the US hegemony, seeks to impose new rules not only to states behavior, but also to international system (Catley 1999). In spite of their apparent preponderance and selfsufficiency, the US is not capable to manage alone the current international system, just as it was pointed out in the EU Security Strategy. The numerous crises outbroken after $1990^{6}$ are eloquent proofs of the American foreign policy ambivalence. Henry Kissinger emphasized that in this transitory international order the US do not want to withdraw from the world, but they are neither capable of dominating it (Kissinger 1998: 17). For this reason, the US has always looked for allies with whom to share the burdens of global management. At the beginning of the 1990s, their choice went naturally towards the European partners and to the EU.

\section{Redefining values}

The end of the Cold War had multiple consequences for Europe's evolution and for its status on the world scene. Many analysts believed that with the fall of the Soviet Union Europe will remain the only power capable to balance US hegemony (Calleo 2004). But, the disappearance of the main enemy challenging its integrity determined the reorientation of Europe towards the enlargement and deepening of the European integration process. Besides enlargement, and as a direct consequence of it, Europe dedicates itself to securing its frontiers, while projecting stability towards its neighborhood. This process is intended to ensure the stability and cohesion of the European construction, and also to make a clear delimitation between Member States and non-Member States, in terms of inside and outside (Hill 2002: 99). The Treaty of Maastricht creating a European Union inaugurates the beginning of a new dialogue in the transatlantic relationship. The EU becomes, beside the member states, a direct interlocutor in the relations with the US. At the same time, it symbolizes the EU's will to affirm itself as a distinct pole in global politics. The EU aims to develop as a political-economical individuality, capable to sustain its own visions and defend its own interest (Sampaio 2004: 4).

The dynamics of the transatlantic partners and the post Cold War realities imposed the redefinition of the transatlantic relationship. The transatlantic solidarity, together with its

\footnotetext{
${ }^{6}$ See The Gulf War, the crisis from Bosnia, Rwanda, Somalia, Kosovo, the 9/11 attacks, the Afghanistan War and the Iraq War.
} 
core values is reaffirmed in the Transatlantic Declaration, in 1990, a joint US-EC declaration that established the main goals of the transatlantic cooperation and announced the future institutional framework for consultations, settled in the New Transatlantic Agenda. The New Transatlantic Agenda, signed on 3rd December 1995, was designed to advance further the transatlantic relationship and to adapt it to European transformations that outlined the EU as a new actor in this partnership, status that is formally recognized by this act. The Agenda is intended for: promoting peace and stability, democracy and development around the world, responding to global challenges, contributing to the expansion of world trade and closer economic relations and building bridges across the Atlantic ${ }^{7}$. Analyzing the values that are referred to in the text, it is easy to trace the basic matrix of values (freedom, democracy, rule of law, human rights), that contributed to the great solidarity between the two shores of the Atlantic. As in the previous documents, defending and promoting these values is considered an interrelated process. Unlike other documents, the Agenda assigns a preeminent role to the economic principle of free trade, on which the two economic superpowers plan to construct a global institution (WTO) with the purpose of regulating global trade. The preeminence of the free trade principle indicates, also, the shift in importance in the transatlantic cooperation, from the strategic dimension (prevailing in the Cold War) to the economic dimension.

Although The New Transatlantic Agenda proposed very ambitious goals concerning the deepening of the relationship and the minimizing of the possible contradictions through intense consultation, in practice there were a lot of things to improve and adjust, on the both sides of the Atlantic, in order to achieve the targets. Little by little, the transatlantic relationship has started to be shaken by internal problems. We do not believe that the drifting apart of the partners can be identified temporarily at a precise date, nor that it coincides with George W. Bush's election. According to John Peterson and Mark Pollack, the tensions in the transatlantic relationship revealed themselves before 2001 and the consequences of the terrorist attacks did not materialize identically in all the domains of interaction $^{8}$ (Peterson, Pollack 2004: 132). Still, there are some changes in the US foreign policy that accelerated the outbreak of the older disagreements: the loss of the transatlantic

\footnotetext{
${ }^{7}$ See http://www.europa.eu.int/comm/external relations/us/new transatlantic agenda/index.htm

${ }^{8}$ For instance, the cooperation in justice and home affairs was advanced, as well as the launch of the Doha Development Agenda.
} 
priority in favour of the war on terror, the US post-Cold War Grand Strategy, the triumph of unilateralism and the Iraq War (Hoffman 2003: 15). At the same time, the EU lacked strategic vision and military capabilities to sustain the burden sharing wanted by the US, and this contributed to the gradually US alienation from their allies. The alienation of the transatlantic partners was reflected in the post-Cold War Era through antithetical positions and solutions adopted by the American and European sides during important international events, doubled sometimes by a hostile rhetoric.

The transatlantic antagonism feeds itself from the different interests of the two parts involved and from the imaginary constructions that each part forms about itself and about the other. The US is seen as a symbol of the desire for power and dominance, and the EU as an irrelevant military and political actor, but also as a potential threat (Gnesotto 2003: 20-33). Amplifying the transatlantic disagreements by massive mediatization produced a generalized debate, not only in the academic circle, but also in the political and bureaucratic ones. In their attempt of explaining the state of the transatlantic relationship some scholars developed the idea of clashing values or different values, denying the existence of the common transatlantic values ${ }^{9}$.

But after decades of collaboration founded on the shared values can we really forget about all the transatlantic achievements and stress only divergence? Have Europeans and Americans drifted so far apart that we can assume that they live in separate worlds? Our answer is definitely no. In order to sustain our argument we will first focus on the traditional European and American values and then analyse the core European and American documents discussing values, norms and principles referring to the global responsibility of the two actors and see whether they are in disagreement or not.

The EU has not yet outlined a clear European identity. Actually, the cultural dimension of the EU integration has just started reason for which culture can be still seen as a source of fragmentation, rather than unity (Schnabel 2005: 81). Discussing the concept of "European values", Gabriel Toggenburg classified them in: values belonging to the EEC, values related to the European identity or European ideas (without legal value) and values stated by the acquis communautaire (Toggenburg, 2003: 11-13).

Thus, the Preamble of the European Economic Community states the creation of a political area characterized by peace and freedom, the ensuring of well-being in a free

\footnotetext{
${ }^{9}$ See Robert Kagan, Jacques Derrida and Jurgen Habermas.
} 
market economy, the supporting of a project that will lead to a higher level of integration and the encouragement of the European solidarity in agreement with the principles of the UN Charter ${ }^{10}$.

Regarding the values related to the European identity, we mention the foundations of the European civilization. The blending of the Greek culture, Roman law and JudeoChristian values moulded a distinctive culture and civilization that bears the marks of millenary historical legacy. At a symbolic level, this inherited identity finds itself in the perception of a Europe built upon "three mountains": the Acropolis, the Capitol and the Golgotha. The European integration was intended as an economic and spiritual rebirth of a Europe declined by ideological confrontations and exacerbated nationalisms. So, we witness a reevaluation of the European values, whose aim is to impose a new European model, released from the determinism of its past.

The Constitutional Treaty, result of a political compromise between the member states, offers a broader definition of the European values. The Article 2 states: "The Union is founded on the values of respect for human dignity, liberty, democracy, equality, the rule of law and respect for human rights. These values are common to the Member States in a society of pluralism, tolerance, justice, solidarity and non-discrimination" ${ }^{\prime 1}$. We observe that, unlike the previous treaties, The Constitutional Treaty brings a more concrete definition of the European values. At the same time, the Treaty inserts the principle of solidarity and nondiscrimination, which remembers the EU preference for a social economy model, with a high level of protection.

So, the European values are a dynamic concept that is directly connected with the evolution of the European integration. Inferring the European values from the political projection of the EU, Tzvetan Todorov points out as European values liberal democracy, pluralism and secularization (Todorov 2005/2006: 17-22). In contrast, Pope Benedict the $\mathrm{XVI}^{\text {th }}$ states the necessity of creating a European identity derived from the European historical conscience. The values that produced such a European Conscience and, implicit, a European identity are: human dignity and human rights, marriage, family and religion (Pope Benedict the XVIth 2006: 23).

\footnotetext{
${ }^{10}$ See the See the Preamble of TEC

${ }^{11}$ http://europa.eu.int/constitution/futurum/constitution/part1/title1/index_en.htm.
} 
The European protests against the Iraq war, in February 2003, made Jürgen Habermas assess the formation of a European identity by underlying the elements that individualize Europe from America. This identity of Europe as Non-America (Garton Ash 2004: 47) is constructed around six main attributes: "the separation of religion from politics; the formative power of the state to correct the failures of the market; a political party system composed of conservatives, liberals and socialists; social justice; moral sensibility; and supranational cooperation". Habermas's identity construction, analyzed more carefully reveals a rather simplistic and uniform view of both European and American identities. By stressing exclusively the elements that divide the two shores of the Atlantic, Habermas not only overbids the importance of these features, but also neglects the common characteristics, which prevail. Moreover, the values considered exclusively as European prove to be pretty similar to the ones promoted by the US Democratic Party (Schnabel 2005: 91). Moreover, as Timothy Garton Ash emphasizes both Europe and America are traditionally characterized by diversity and division. For instance, America is divided between the debates generated by supporters of unilateralism and those arguing in favour of a multilateral approach, while Europe oscillates between Euro-Atlanticism ${ }^{12}$ and Euro-Gaullism ${ }^{13}$ (Garton Ash 2004: 123).

If the "European identity" needs a lot of time and political will to mature, the American identity and the American values experience the same dynamics. The American values formed simultaneously with the American nation and the American state. Even from the beginning, these values were considered superior and exceptional to any existent model.

The Declaration of Independence is the first official document that refers to the American principles: liberty, equality, separation of powers and the pursuit of happiness.

The US Constitution develops the points expressed in the Declaration and confirms as American values: justice, security, general welfare and liberty.

The American values shaped a national identity whose guide marks are: AngloSaxon protestant culture ("WASP"), dissidence ("the liberty spirit"), American Creed, the individualism, work ethic, religiosity and civil religion (Huntington 2004: 45-77). Referring to American Creed, Martin Lipset identifies liberty, chance equality, individualism and laissezfaire spirit as foundations of the American conscience (Lipset 1996: 63-64). Alexis of Tocqueville believed that the specific feature of the American civilization lays in the

\footnotetext{
${ }^{12}$ Europe as US's partner.

${ }^{13}$ Europe as non-America.
} 
successful blending of two different elements, yet reinforcing each other: the religious spirit and the liberty spirit (Tocqueville 1995: 87). The essential role played by the religious spirit and the liberty spirit in the process of constructing the American identity can be easily noticed at the symbolic level. The devices In God We Trust and Annuit Coeptis, together with the presence of the Liberty Goddess on all the American currencies indicate not only their primordiality for the American identity, but also the belief that these values are unique and exceptional.

The American values have always been in a permanent connection with the US foreign policy. From the moment when the US renounced at their isolationist policy typical of the $19^{\text {th }}$ century and of the beginning of the $20^{\text {th }}$ century, the spreading of their own values became one of the key targets of the American foreign policy. Walter McDougall pointed out that America redefined itself from a "promised land" into a "crusader state" (McDougall 1997). The conscience of superiority, oneness and that of the exceptional destiny strengthen the confidence in the capacity of transforming the world in accordance with the American model. This offensive for the ideological conquest of the world received most of the times messianic and moralizing attributes. A foreign policy in realist terms (power, national interest) never gained the mass support. Therefore, the foreign interventions were presented not as national gains, but as moral finalities (Dallek apud Lepgold, McKeown 1995: 374).

Analyzing the dynamics of American values and the impact they have on the stage of international politics we noticed a paradox. On the one hand, the continuity and stability of the norms and principles put forward by the US. After the collapse of the communist regimes the traditional American values were brought again in foreground in order to be exported to the newly democratized countries through aid programmes, NGOs or through the enlargement of western international organizations. But on the other hand, considering the support of the public opinion towards the American foreign policy, we note the outlining of a fracture between the vision of the elites and those of the rest of the population. As Eric Alterman emphasizes, the elites tend to favour the US messianism of building the world in accordance to the American pattern, while the masses declare themselves for respecting and promoting the American values back home (Alterman 1996). In addition, the main poles show a decline in the public opinion support towards an active foreign policy. In our opinion, this phenomenon is the consequence of several factors 
among which we consider the US status of superpower that is associated by Americans with the lack of need of an external engagement and also the changes occurred in the American culture and beliefs. The American "melting pot" has evolved during the last years into a more "pluralistic culture" (Piciocchi 2003: 33). The traditional American values, as stated in the US Constitution maintain their validity, but the interference of thousands of cultures has diminished the preponderance of the traditional Anglo-Saxon culture. Alain Minc argues that on long term this phenomenon may probably generate a loss in importance of the traditional transatlantic values, due to the new identity synthesis (Minc 2004: 117-118). However, we think that it is still very difficult to anticipate changes at the collective mental level. For now, the messianic beliefs, for which the United States renounced at their isolationist policy and engaged in the world, by creating solid alliances, are still deeply rooted in the American conscienceness. This proves that the transatlantic values could be easily reactivated, because their essence has not been altered.

In addressing the problem of European values/ American values in their relation to the transatlantic values and transatlantic relationship, we must analyze the implications of the EU multilateralist approach, approach that has often been interpreted as the fundamental antagonic principle in its relationship with the US. Multilateralism is according to John Ruggie "an institutional form which coordinates relations among three or more states on the bases of generalized principles of conduct” (Ruggie 1993: 14). Furthermore, James Caporasso defines multilateralism as "a demanding organizational form that requires its participants to renounce temporary advantages and the temptation to define their interest narrowly in terms of national interests, and it also requires them to forgo ad hoc coalitions (Caporasso apud Pollack 2004: 116 ).

Starting from these definitions and relating them to the core European documents can we consider EU's multilateralist approach as a new European value, or more as means of solving the global problems? And if so, does it enter in contradiction with the American values and the transatlantic values? The European preference towards multilateralism evolved from the tradition of a permanent negotiation and from its subordination to the UN and the international law. According to Thomas Mowle's epistemic hypotheses, the EU's support for multilateral policies reflects"the congruence with the national policies already adopted" (Mowle 2004: 29). 
The Constitutional Treaty refers to the EU objectives regarding global responsibility, acknowledging that "In its relations with the wider world, the Union shall uphold and promote its values and interests. It shall contribute to peace, security, the sustainable development of the earth, solidarity and mutual respect among peoples, free and fair trade, eradication of poverty and protection of human rights and in particular children's rights, as well as to strict observance and development of international law, including respect for the principles of the United Nations Charter" ${ }^{\prime 14}$. The Treaty confers the EU increased powers on external level by establishing its juridical personality and a ministry of foreign affairs. These juridical and institutional changes prove that the EU aims to distinguish itself as a responsible international actor, promoting on the strength of this status its defining values. Among the goals stated by EU, we notice the insistent use of some objectives such as development and humanitarian aid. Representing a target of the EU on the whole, development and humanitarian aid are interrelated with different external policies of the EU. The EU's sensibility towards these aspects demonstrates its outlining as a pole of "soft power". The EU's policies of reconstructing Bosnia, Kosovo, Afghanistan, and Iraq, the financial aids given to Ethiopia, Eritrea, Niger and Indonesia have transformed the EU into a world leader concerning humanitarian aid and development. This "soft" European approach is due, on the one hand, to the lack of military and logistics capabilities, and, on the other hand, to Europe's reconfiguration, through EU's agency, in a pacified and pacifying entity. As Parag Khanna noted, EU individualizes itself on the international stage precisely through redefining the old notions of power and influence (Khanna 2004: 69).

Another relevant document for the EU's principles regarding global responsibility is the European Security Strategy, entitled A Secure Europe in a Better World. The so-called "Solana Document" presents the international security environment, underlying the contemporary challenges and threats ${ }^{15}$, but also the imperative to act together in order to ensure the global security, because "No single country is able to tackle today's complex problems on its own". The Strategy reaffirms the EU commitment "to an effective multilateral system and to the upholding and development of the international law". Therefore, the EU vision of global responsibility is one of a coordinated action of the

\footnotetext{
${ }^{14} \mathrm{http} / /$ europa.eu.int/constitution/futurum/constitution/part1/title1/index en.htm
}

${ }^{15}$ Terrorism, WMD proliferation, regional conflicts, state failure, organized crime. 
transatlantic allies, a joint action that can develop into a transatlantic strategic partnership (Cooper 2003: 165). Furthermore, the Document transposes the EU's view towards preventive action, by appealing to a large range of means, not only to the diplomatic ones. So, the EU proposes as a viable alternative the spreading of good governance, support for social and political reforms as well as for the rule of law, fighting corruption, and the protection of human rights. This vision is illustrating for the normative content of the European Union's approaches, the Union imposing conditions to the other states according to its own norms with the aim of preventing or of constructing/reconstructing (Coker 2004: 30). Hence, the EU gives priority to the solution of the insecurity sources through development policies, fighting against terrorism, focusing first of all on solving the causes that generate the main problems.

The EU adhesion to the multilateral approach is also marked in the statements of important EU leaders. President Barroso, as well as the Commissioner for External Affairs, Benita Ferraro-Waldner, like to remember in their speeches the EU commitment towards global responsibilities ${ }^{16}$, commitment that can be successful only by respecting the multilateral international framework and the legality of any action. Nevertheless, the EU official declarations are far from being biting towards the US's external policy. Although they state the European Union's preference for multilateralism and legalism, the statements always outline the need for transatlantic cooperation, at every level of interaction concerning the transatlantic interests and the global problems. This diplomatic language reflects the EU's wish that its status of rising global power to be recognized by the US.

The multilateralism promoted by the EU was considered by Robert Kagan as a direct consequence of Europe's military and strategic irrelevance, as a form of fear of international engagement and method of limiting the US hegemony (Kagan apud Dobrescu 2003: 262). By portraying the Americans and the Europeans as antagonic nations, permanently stressing Europe's military and strategic irrelevance and announcing the rift in the transatlantic relationship, Robert Kagan neglects a series of facts. First of all, Kagan reduces the transatlantic relations to strategic and military relations. But the transatlantic relations represent a dense and complex network of interactions, which include economic, political, cultural, and social relations. Then, considering the discrepancy in military

${ }^{16}$ See Building a Transatlantic Alliance for the 21st Century - speech by Benita Ferrero-Waldner and The $E U$ and the US: a declaration of interdependence- speech by J. M. Barroso. 
capabilities, Kagan concludes with a general characterization of the state of the US-EU relations that insists on the breaking off. The transatlantic relations distinguish themselves by their ambivalence, the economic relations being more integrated and stable than the political and strategic ones. Therefore, the US-EU relations cannot be labeled only by the state of the political and strategic relations. Such an overall and reductionist characterization is distorted and does not reflect the complexity of the transatlantic interactions. Moreover, it is true that the EU does not posses the necessary military capabilities as to consider itself a great power, but the concept of power itself has changed in the last years. It is no longer equalized with material and military power. The economic power and the power of influencing the others are as important acquisitions as the military ones. This argument was developed by Kalypso Nikolaidis, who talks about the "power of the superpowerless", meaning the EU's ability of exporting its own model, principles and values due to the prestige of its institutions and policies (Nikolaidis 2004: 96). In accordance with this argument, we exemplify the desire of Turkey, Croatia, Ukraine and Republic of Moldova of becoming EU members, desire that certifies the fascination that the EU enjoys.

Multilateralism is a specific EU approach, due to the institutional nature of the European Union, which was constructed by balancing interests in the form of compromises. Still, it is not a value per se, but more a means of promoting the EU interests and values, because the support for multilateralism remains selective and conditioned. The Kosovo intervention without the Security Council's agreement, the subsidies granted by the Common Agricultural Policy, the ban on hormone-treated beef against the WTO regulations, suggest that multilateralism is for the EU, beyond its own institutional framework, a mean of advancing its domestic priorities (Pollack 2004: 127).

If the EU sustains a multilateral approach, the US favours a unilateral one. The American unilateral policy was officialized after the 9/11 events. It distinguishes itself through a particular attitude towards the international institutions, allies and ancient foes, based on non-engagement, superiority and lack of interest ${ }^{17}$. The main document that brings the unilateral approach on the US national security agenda is George W. Bush's Grand Strategy.

The New Strategic Doctrine, revealed in September 2002, states the preemptive war, not only against the non-state terrorists groups, but also against the states suspected to

\footnotetext{
${ }^{17}$ See US position towards UN, US hostile attitude towards the "Old Europe".
} 
support the terrorist groups. The Strategy is based upon two concepts: the preemptive strikes and the regimes' change. According to Andrew J. Bacevich, it raises military power at the rank of the most effective instrument of statecraft (Bacevich 2002). The Grand Strategy combines the American exceptionalism, with the hegemonic approach and the spread of the universal values of liberties (Haine 2003: 109). Appealing to the values of political and economical liberty, the authors of the strategy seek to justify and legitimize future actions. Although it sanctions the unilateral approach of the US, the strategy mentions the necessity of strengthening the alliances for defeating global terrorism.

Evaluating the Strategy we noticed the tendency of presenting the world politics as an ideological conflict between the "free world" and the "unfree world". So, the Strategy, as the whole rhetoric used by George W. Bush dramatises possible threats to the national security. While in the Cold War the US were constantly relating themselves to their number one enemy, the Soviet Union, we perceive now a shifting of alterity from communism to terrorism as the main threat. Therefore, the fight against terrorism can be seen from a triple hypostasis: as a value per se due to the appeal to ideology, as a means of maintaining the US hegemony and as an end for securing the foreign policy agenda. Regarding the value of human rights, we notice that the commitment to protect and promote the human dignity is connected to the need of interfering against the oppressive regimes with the aim of encouraging change and democracy. So, the moral integrity of defending human rights oblige, in the American view, to active and immediate involvement for restoring such dignities.

The Grand Strategy has been especially illustrated in the Iraq war, when the military operations were planned without NATO cooperation and when the Americans used bilateral engagements between the US and some European states to form ad-hoc coalitions. The implications of this decision have produced considerable change in the transatlantic relationship: the solidarity notion, as one of the most important principle in the transatlantic alliance, was replaced by a cooperation “à la carte” (Geré 2004).

US support for the unilateralist approach is more reserved in the statements regarding to the transatlantic relationship. The American rhetoric outlines the historical cooperation between the two sides and invites the European partner to engage in the global crusades against terrorism. This ambivalent attitude indicates the American preoccupation 
for ensuring a legalist façade to their approach, but also shows its expectations for a European burden sharing of global responsibilities.

Analyzing the evolution of the transatlantic values, it is easy to confirm the continuity and viability of the normative dimension in the transatlantic relationship. The basic transatlantic values continue to be shared by both leaders and public opinions in the transatlantic area. It is true that both the US and the EU find themselves in a process of redefining and internal and external reevaluation, which also implies shifts at the value level. By this, Europe has renounced its long forgotten traditional balance of power principles, preferring to assume now a new identity, in accordance with the realities and the objectives of the European project. Simultaneously, the US rejected in part its values of noninterventionism and multilateralism to take advantage of its hegemonic status.

As Timothy Garton Ash emphasizes, the transatlantic community did not divide itself in Europeans and Americans after the start of the Iraq War (Garton Ash 2004: 9). Actually, the social dimension of the transatlantic relationship ensures the preservation of the transatlantic values. The poll Transatlantic Trends, carried on in 2005, shows that Europeans and Americans have a common position regarding the promotion of democracy. $71 \%$ of Europeans and $51 \%$ of Americans support the advancing of democracy, on which they relate to peaceful means (by monitoring elections, economic and political sanctions). Also, most of the Europeans (54\%) and of the Americans (52\%) believe that both the US and the EU should set up economic sanctions to China for violating human rights ${ }^{18}$.

The two distinct approaches towards global responsibility, the EU multilateralism and the US unilateralism, are not two contrasting values, but different means of promoting their own values and interests, which in essence are the same: respecting and advancing democracy, freedom, market economy and human rights. The US and the EU continue to found on the same values, the transatlantic values, which are still central to the American and European values. Therefore, we suggest that the disagreements in the transatlantic relationship do not arise from the antagonism of values, but from the way of transposing them into practice.

\footnotetext{
${ }^{18}$ See Transatlantic Trends 2005
} 


\section{Conclusions}

Concluding this paper, we must to point out some reflections concerning the future of the transatlantic relations:

1. The American unipolar moment would not resist for an indefinite time because in a globalized world no country allows itself to maintain its hegemony for a long period. An eloquent example is the US current account deficit, the loss of American public opinion support for the Iraq War and the failure to stabilize Iraq. The unilateral approach is not sanctioned favourably by the European allies; it generates frustration and discontent, which on long run may result in a loss of moral authority and in a coalition of competitors aiming to balance American hegemony. In this unipolar structure, the US do not have the capacity, nor the domestic support and the political will to engage themselves strategically in different parts of the world.

2. The idea of a global strategy formulated by President Bush can be successful only if based on the transatlantic partnership, the most enduring alliance in history. Only a joint transatlantic action can restore the legitimacy of the American actions.

3. Therefore, the internal balancing of the transatlantic alliance is imposed as a necessity favoring both parties and in the sense of a genuine partnership of equals. 


\section{References:}

Bacevich, Andrew, J. 2002. Bush's Grand Strategy. The American Conservative, http://www.amconmag.com/2002/2002 11 04/bushs grand strategy.html (8.01.2006).

Calleo, David, P. 2004. Geopolitics and the Broken West, www.saisjihu.edu/faculty/calleo/China\%2520speech.doc (5.04.2005).

Castells, Manuel. 1997. The Power of Identity. Malden, MA: Blackwell.

Catley, Bob. 1999. Global America: will the unipolar moment pass? Paper presented at the third Wellington Conference World Affairs, http://www.vuw.ac.nz/pols/Journals/Antepodium/articles/catley-1999.aspx (10.03.2005).

Coker, C. 2004. The US and its global vision: Europe - US Alliance post Iraq war. In The United States and the World, edited by Suominen Terhi, Kytömaa Eero, 27-33. Helsinki: Atlantic Council of Finland.

Cooper, Robert. 2003. The breaking of nations: Order and Chaos in the Twenty-First Century. London: Atlantic Books.

Dobrescu, Paul. 2003. Geopolitica. Bucuresti: Comunicare.ro.

Garton, Ash, Timothy. 2004. Free World: America, Europe and the surprising future of the West. New York: Random House.

Geré, François. 2004. The Transatlantic Partnership: from a troubled love story to a pragmatic grownup relation, http://www.diploweb.com/english/transatlantic.htm (12.05.2005).

Gnesotto, Nicole. EU, US: visions of the world, visions of the other. In Shift or Rift: Assessing US-EU relations after Iraq, edited by Lindstrom Gustav, 21- 42. Paris: EU Institute for Security Studies.

Gouré, F. 2004. The Limits of Alliances: The Decline of America's Traditional Alliances and the Search of New Allies. Arlington: Lexicon Institute.

Haine, Jean- Yves. 2003. Power without restraint? Back to realities. In Shift or Rift: Assessing US-EU relations after Iraq, edited by Lindstrom Gustav, 105- 126. Paris: EU Institute for Security

Studies.

Hill, Christopher. 2002. The geopolitical implications of enlargement. In Europe Unbound, edited by Zielonka Jan, 95- 113. London: Routledge. 
Hoffman, Stanley. 2003. The crisis in the transatlantic relations. In Shift or Rift: Assessing US-EU relations after Iraq, edited by Lindstrom Gustav, 13- 20. Paris: EU Institute for Security Studies.

Huntington, Samuel. 2004. Cine suntem? Provocările la adresa identității naționale americane.

Filipeştii de Târg: Antet.

Khanna, Parag. 2004. The Metrosexual Superpower. Foreign Policy, no. 143: 66-68.

Kissinger, Henry. 1998. Diplomatia. Bucuresti: All.

Kupchan, Charles. 1998. Atlantic Security: Contending Visions. New York: Council on Foreign Relations.

Lepgold, Joseph, McKeown, Timothy. 1995. Is American Foreign Policy Exceptional? An empirical Analyses. Political Science Quarterly, vol. 110, no. 3: 369-384.

Lipset, Martin, S. 1996. American Exceptionalism: A Double- Edged Sword. Norton, New York: Norton.

McDougall, Walter. 1997. Promised Land, Crusader State: The American Encounter with the World Since 1776. Boston: Houghton Mifflin.

Minc, Alain. 2004. The U.S. and Europe: Three Questions and Four Scenarios. In Conflict and Cooperation in Transatlantic Relations, edited by Hamilton Daniel S., 117- 129. Washington, D.C.: Center for Transatlantic Relations.

Nikolaidis, Kalypso. The Power of the Superpowerless. In Beyond Paradise and Power: Europeans, Americans and the Future of a Troubled Partnership, edited by Tod Lindberg, 94- 120. London: Routledge.

Peterson, John, Pollack, Mark. 2004. Conclusions: The end of the transatlantic partnership? In Europe, America and Bush. Transatlantic Relations after 2000, edited by Peterson J., Polack M., 128- 143. New York: Routledge.

Pfaltzgraff, R., Dougherty, J. 1990. Contending Theories of International Relations. London: Harper Collins.

Piciocchi, Cinzia. 2003. Cultural Diversity at the Background of the European Debate on Values. In European Constitutional Values and Cultural Diversity, edited by Palermo Francesco, Toggenburg, G, 22- 34. Bolzano: European Academy.

Pond, Elizabeth. 2004. Friendly Fire: The Near Death of the Transatlantic Alliance. Washington D.C.: Brookings Institution Press.

Pope Benedict the XVIth. 2006. Europe and Its Discontents. First Things, no 159: 16-22. 
Ruggie, John. 1993. Multilateralism Matters. New York: Columbia University Press. Mowle, Thomas. 2004. Allies at Odds?The United States and The European Union. New York: Palgrave Macmillan.

Sampaio, J. 2004. Transatlantic Relations: Perspectives from Portugal. In Conflict and Cooperation in Transatlantic Relations, edited by Hamilton Daniel S., 3- 13. Washington, D.C.: Center for Transatlantic Relations.

Schnabel, Rockwell, A. 2005. The Next Superpower? The Rise of Europe and Its Challenge to the US. Lanham: Bowman\& Littlefield Publishers.

Serfaty, Simon. 2005. The Vital Partnership. Power and Order. America and Europe Beyond Iraq. Lanham: Bowman\& Littlefield Publishers.

Tocqueville, Alexis. 1995. Despre Democratie in America. Bucuresti: Humanitas.

Todorov, Tzvetan. 2005/2006. European Values. Salmagundi 148/149: 16- 22.

Toggenburg, G., N. 2003. Cultural Diversity at the Background of the European Debate on Values. In European Constitutional Values and Cultural Diversity, edited by Palermo Francesco, Toggenburg, G , 11- 21. Bolzano: European Academy.

Wohlforth, C. W. 2004. The transatlantic dimension. In European Union Foreign and Security Policy. Towards a neighbourhood strategy?, edited by Dannreuther Roland, 186- 201. London: Routledge. 